\title{
Diversity of Molluses (Gastropod And Bivalve) In Mangrove Ecosystem of Oransbari District, South Manokwari Regency, West Papua Province, Indonesia
}

\author{
Markus Waran', Marlon I. Aipassa $^{2,3}$, Jacob Manusawai ${ }^{2}$, Anton S. Sinery ${ }^{2,4^{*}}$ \\ ${ }^{1} \mathrm{PhD}$ student of environmental sciences programs of Papua University \\ ${ }^{2}$ Postgraduate programs of Papua University \\ ${ }^{3}$ Forestry Faculty of Mulawarman University \\ ${ }^{4}$ Environmental Research Centar of Papua University, Indonesia, Amban Manokwari 98313
}

Received: 07/06/2020 Accepted: 30/07/2020 Published: 27/07/2020

\begin{abstract}
In the Oransbari mangrove ecosystem, 13 species of molluscs were identified with 1256 individuals consisting of 9 species of gastropod and 2 species of bivalve. Dominance index of the identified molluscswas 0.11 , with species diversity index of 1.89 (medium category) and species evenness index of 0.76 (high category).
\end{abstract}

Keywords: Diversity, Molluscs, Gastropod, Bivalve, Mangrove Ecosystem, South Manokwari

\section{Introduction}

Mangrove in South Manokwari Regency is one of the potential mangrove ecosystems that could be intensively managed by local government to support the sustainable development goals. This is based on change of function of forest area for development and optimization of the environmental quality index through efforts to increase the area of protected areas to $47 \%$ (41,691 ha) from the current condition of $46 \%$ (41,306 ha). Besides, as an effort to maintain mangrove ecosystem related to its function as a buffer against abrasion and tsunami, the habitat of various types of aquatic biota, mangrove also plays an important role in community livelihood through the utilization of aquatic biota, especially fish, crabs, shrimp and mollusks.

Management of mangrove ecosystem in Oransbari district is applied through the intensive management plan of the Oransbari mangrove forest area in order to particularly support the area of West Papua mangrove forests $4.81 \%\left(4,791.29 \mathrm{~km}^{2}\right)$ of total area as well as to maintain in general the Indonesia mangrove forests which reaches 3.2 million ha $(22,4 \%)$ of world. The target plan is ongoing with the commitment of maintaining 39\% of marine protected area and $57 \%$ of terrestrial protected area

Corresponding author: Anton S. Sinery, (a) Postgraduate programs of Papua University and (b) Environmental Research Centar of Papua University, Indonesia, Amban Manokwari 98313. Mobile phone: 085244308802. E-mail: anton_sineri@yahoo.com through the revised of West Papua spatial planning document (1). According to (1), West Papua currently has $39 \%$ of marine protected area and 55-60\% of terrestrial protected area, in the revised of West Papua spatial planning 2013-2033.

Molluscais a group of organisms that play an important role in ecosystem mangroves, as it is often used as environmental bioindicator. According to researchers mollusca is the second most common phyla after Arthropods consisting of Polyplacophora (chitons), Gastropods (snails), Bivalvia (clams), Scaphopods (hornshells), Cephalopods (squid or octopus), Aplacophora and Monoplacophores and Monoplacopora. From those seven classes, Gastropoda and Bivalvia are considered as the largest classes of molluscs (2). Both of them play an important role in ecology (the food chain), as well as in supporting the economic life of the coastal community. Mangrove gastropods are detritus-eaters that play a role in breaking down fresh litter, as well as accelerating the process of litter decomposition by microorganisms (3). According to (3), molluscs are beneficial to humans including as a source of protein, animal feed ingredients, industrial materials, jewelry, fertilizer materials and medicines. For instance, several species of molluscs such as Terebralia palustris, Telescopium telescopium, Cerithidea obtusa (3). Moroever, some speciessuch as Anadara granosa, Gelonia erosa, Anadara pilula, Gelonia expansa, Isognomon ephippium, Faunus ater and Cerithideopsilla cingulata are generally consumed by coastal communities, especially in the regions of Papua and West Papua.

Oransbari mangrove ecosystem with total area of 384,9 ha is 
one of the mangroves in the region that has potential flora, fauna and ecosystem services that are worth to be developed. One of mangrove potencies is molluscs species, especially gastropod and bivalve which have ecological and economic importance for the ecosystem and coastal community. According to interview and field observation, there are several types of molluscs in this region, but they are not yet scientifically identified. Therefore, the research aims to identify types of molluscs particularly species of gastropod and bivalve in Oransbari mangrove ecosystem.

\section{Material dan Methods}

This research was conducted in mangrove ecosystem of Oransbari district, South Manokwari Regency, West Papua Province, Indonesia. The study was done for two months from January to February 2020. The equipments used consisted of GPS (Global Positioning System), levers, plastics, collection bottles, tweezers, digital camera, vernier caliper, surgical boards, gauges, raffia and stationery. The materials used were label paper and alcohol $70 \%$ and formalin.

The research was using descriptive method with observation techniques. The observation station was determined using purposive sampling which isconsidering the zonation of mangrove vegetation. The Oransbari mangrove ecosystem hasspecies relatively similar with a forest width of approximately $120-1000 \mathrm{~m}$. Consideringthe condition, the observation sites (sampling stations) was determined in one transect $120 \mathrm{~m}$ long dominated by Sonneratia sp, Rhizophora sp, Avicennia sp, Bruguera gymnorhiza. Each site had four obsevation plots with size of $10 \mathrm{~m} \times 10 \mathrm{~m}$.

The main variables observed were morphological characters of mollusca (gastropod and bivalve) in form of color, body size (length, width, diameter expressed in $\mathrm{cm}$ ) in order to determine the species and number of individuals. Moreover, general condition of study site was documented. Collecting samplesof molluscs (gastropod and bivalve) weredone at low tide and in sunny day. The samples on substrate and attached to mangrove roots (inside the plot) were taken entirely. The collected samples thus were preserved using alcohol $70 \%$ and put into specimen box. Furthermore,the samples were identified using the journal (4), (5), (6), (7), (8), (9), (10), (11), (12). The collected data were analyzed qualitatively and quantitatively based on each parameter and therefore presented in tables and figures (charts, graphs and photographs). To determine the abundance of species in the area, the equation was used as follows:

$$
\mathrm{A}=\frac{\mathrm{xi}}{\mathrm{ni}}
$$

Note: $\mathrm{A}=$ Abundance (number of individual $/ 20 \mathrm{~m} 2$ ); $\mathrm{xi}=$ number of individuals; ni $=$ Number of squares. The concentration of individual species of mollusca wasdetermined usingindex of domination (C) (Simpson, (1949) in (13) as followed:

$\mathrm{C}=\left(\frac{\mathrm{ni}}{\mathrm{N}}\right)^{2}$

Note: $\mathrm{C}=$ index of dominance; $\mathrm{ni}=$ number of individuals of a species; $\mathrm{n}=$ number of individuals of all species. Dominationisa community characteristic that shows the abundanceof species in a region (Odum, 1971 in 13). The criteria of domination index according to Odum (1993) are: 0 $\langle\mathrm{C}\langle 0.5=$ Thereare no dominant species; $0.5>\mathrm{C}\rangle 1=$ Thereare dominant species. To determine the diversity of mollusca as an indicator of habitat, species index diversity $(\mathrm{H})$ according to Shanon and Wiener (1949) in (13) was used with the equation:

$H=-\sum\left[\frac{n i}{N}\right] \ln \left[\frac{n i}{N}\right]$

Note: $\mathrm{H}=$ diversity index (Shanon-weinner index); ni = Number of individuals of a species, $\mathrm{N}=$ Number of individuals of all species. Shanon and Wiener (1949) in (13), species diversity was considered high if the species diversity index was more than three $(H \geq 3)$, medium if species diversity index was between one to three $(1<\mathrm{H}<3)$ and low if species diversity index was less than one $(H<1)$. The evenness of species of mollusca at the study site was analyzed using the index of evenness (e), according to (13) as follows:

$\mathrm{e}=\frac{\mathrm{H}^{\prime}}{\operatorname{LogS}}=\frac{\mathrm{H}^{\prime}}{\mathrm{Hmax}}$

$\operatorname{Hmax}=2 \ln s$

Note: $\mathrm{e}=$ species evenness index $\mathrm{H}=$ species diversity index; $S=$ Number of species. Evennessindex according to Krebs (1985) in (14) ranged from 0-1, where: 0.6-1 = high species evenness; $0.4<\mathrm{e}<0.6=$ moderate species evenness; 0 $04=$ low species evenness.

\section{Results and Discussion 3.1 Species Composition}

Based on the identification of the morphological characteristics of the mollusca body, 13 species of molluscs were identified, consisting of 7 families and 9 species of gastropod, 2 families and 4 species of bivalve (Table 1). The result as shown in Table 1 showed that the composition of molluscsfound in Oransbari mangrove ecosystem was smaller compared to (15) there were 30 species found in Tanjung Jara, Terengganu beach, Peninsular Malaysia, 11 species were found in Northeast Algeria (16), 15 species were found in the mangrove ecosystem of Lubuk Kertang village, North Sumatra (17), 65 species were found in the waters of Ambon Island, Indonesia (18), (12) which identified 75 species of gastropod and 19 species of bivalve in South Biak Papua. (11) found 14 species of gastropod and 1 species of bivalve in mangrove forets of Dedap Village, Tasikputripuyu Kepulauan Meranti regency in Riau Province. (10) recorded 15 species of gastropod in TPI Parit 7, Tungkal I village, West Tanjung Jabung and 16 species of gastropod in the mangrove forests of Teluk Awur Jepara (19), (20) reported 33 species of gastropod in the mangrove ecosystem in the Gugus Pari Island, and 29 species of gastropod in the mangrove forest area of Segara Anakan Cilacap (21). Many speciesof gastropod were found in those studies due to the wider research location and longer sampling time. While in this research, the location of the research was small, the sampling 
time was limited and many species have been hunted by local people for consumption purpose.

Table 1: Composition of Molluscs in the Oransbari Mangrove Ecosystem

\begin{tabular}{|c|c|c|c|}
\hline Family & Species & $\begin{array}{l}\text { Indiv } \\
\text { idual }\end{array}$ & $\begin{array}{c}\text { Percent } \\
(\%)\end{array}$ \\
\hline \multicolumn{4}{|l|}{ Gastropod } \\
\hline 1 Neritidae & Nerita articulata, Gould, 1847 & 192 & 15,29 \\
\hline 2 Terebridae & $\begin{array}{l}\text { Terebralia palustris Linnaeus, } \\
1767\end{array}$ & 161 & 12,82 \\
\hline 3 Potamididae & Cheritidea $\mathrm{sp}$ & 149 & 11,86 \\
\hline 4 Trochidae & Monodonta sp & 143 & 11,39 \\
\hline 5 Neritidae & Nerita signata, Lamarck, 1822 & 141 & 11,23 \\
\hline 6 Littorinidae & Littoraria scabra Linnaeus, 1758 & 125 & 9,95 \\
\hline 7 Neritidae & Vittoida turrita, Gmelin, 1791 & 124 & 9,87 \\
\hline 8 Muricidae & $\begin{array}{l}\text { Chicoreus capucinus Lamarck, } \\
1822\end{array}$ & 118 & 9,39 \\
\hline $\begin{array}{l}9 \text { Ellobidae } \\
\text { Bivalve }\end{array}$ & Cassidula $\mathrm{sp}$ & 7 & 0,56 \\
\hline 10Corbiculidae & $\begin{array}{l}\text { Gelonia expansa (Mousson, } \\
1849 \text { ) }\end{array}$ & 50 & 3,98 \\
\hline 11 Corbiculidae & Gelonia erosa (Solander, 1786) & 24 & 1,91 \\
\hline 12 Arcidae & $\begin{array}{l}\text { Anadara granosa }, \text { Linnaeus, } \\
1758\end{array}$ & 12 & 0,96 \\
\hline 13 Arcidae & $\begin{array}{l}\text { Anadara antiquate, Linnaeus, } \\
1758\end{array}$ & 10 & 0,80 \\
\hline Amount & & 1256 & 100,00 \\
\hline
\end{tabular}

\subsection{Domination, Diversity and Evenness Index of Molluscs}

The level of species domination, variation of species and evenness of species as indicators of community stabilization in the Oransbari mangrove ecosystem were analyzed using the dominance, diversity and evenness index approaches. The results of the analysis of dominance index, diversity index and evenness index of molluscs species at the mangrove ecosystem could be seen in the following Figure 1. Based on field observation, Nerita articulata was the species with the highest number of individuals found at the study sites. OtherwiseCassidula sp and Anadara antiquate were recorded as species with smaller number of individuals. It could be seen as well that distribution of the species tended at the four observation plots. The location was dominated by anchor root plants (Rhizopora sp.). In addition, several species of gastropod particularly Terebralia palustris andfour species of bivalve (Gelonia expansa, Gelonia erosa, Anadara granosa and Anadara antiquate) found in the study location were known to be consumed by local community.

Fig. 1 presented dominance index of the mollusca species in Oransabari mangrove forest was 0.11 (this indicated there wasno certain of dominant species in the area). According to (13) in (20), the dominance of certain species explained the species that were more focus on an areaand had greater influence in the community. According to Odum (13), when the value of dominance index reached 1 , then only one species was dominant in a community. Conversely, when the value of dominance indexwas 0 , it indicated that there was no dominant species in a community.

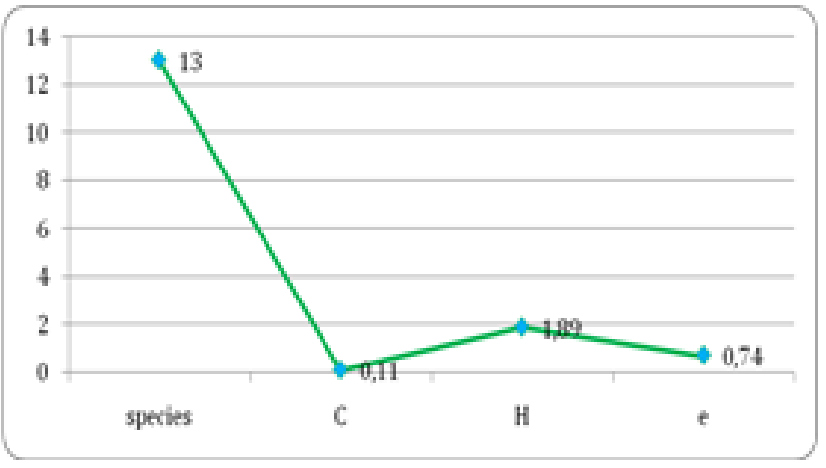

Figure 1: Domination index $(\mathrm{C})$, diversity index $(\mathrm{H})$ and evenness index (e) of molluscs species in the Oransbari mangrove ecosystem

The result showed that diversity index of mollusca in the Oransbari mangrove ecosystem was 1.89 . The study found species diversity of sitewas considered in the medium category. According to (13), species diversity was consideredhigh if the species diversity index was more than three $(\mathrm{H} \geq 3)$, medium if species diversityindex was between one to three $(1<\mathrm{H}<3)$ and low if species diversityindex was less than one $(\mathrm{H}<1)$. Based on these criteria, the diversity of species of mollusca in the Oransbari mangrove ecosystem area was belong to medium category. (13) assertedthat a communitywould havehigh species diversity if the community was composed of many species with the similarabundance or almost the same. Conversely, if the community was composed of several species and if only a very few species were dominant, then the species diversity was low. In addition, (22) stated that the level of species diversity could describe the stability of ecosystem, when the diversity of species in an area is higher, the ecosystem tends to be more stable and it would develop interaction of species which could involve transfers energy, competition and more complex division of space.

Analysis of species evenness level showed that value of evenness index of mollusca species in Oransbari mangrove forest was 0.76. (13) stated that the evenness value was considered high when $\mathrm{e} \geq 0.6$, moderatewhen $\mathrm{e}=0.4<\mathrm{e} \leq 0.6$ and low when $\mathrm{e}=0<\mathrm{e} \leq 0.4$. Based on the criteria, the evenness index of mollusca in the Oransbari mangrove forest was high. The valueof species evenness index,according to (14), ranged from 0 to 1 . According to (22), the evenness index of species indicated the size or proportion of individuals of each species in a community. If each species had similar number of individuals, then the community had maximum value of evenness index.

The result revealed that allspecies of mollusca were mostly distributed in all monitoring plots. This indicated that all species were inhabitants of Oransbari mangrove ecosystem. This condition was influenced by habitat components such as the distribution of vegetations and substrates. Generally, the evenness of molluscain the study site was mostlyinfluenced by the presence of mangrove vegetations namely Rhizophorasp as well as other species such as Sonneratia sp, Avicennia sp and Bruguera gymnorhizawhichwere considered as source of organic material and habitat for molluscas. Moreover, condition ofmud substrate in the area of study becamea factor that affected the presence of mollusca in the ecosystem. (10) found outthat characteristics ofhabitat and environmental conditions such as temperature, $\mathrm{PH}$, salinity and types of substrate were factors that 
greatly influence the presence of mollusca beside the condition of the mud substrate.

\section{Conclusions}

The total number of individual and species of gastropod and bivalve identified in the Oransbari mangrove forest were 13 species with 1256 individuals consisting of 9 species of gastropda and 4 species bivalvia. The dominance index of the identified molluscain the Oransbari area was 0.11 with the species diversity index of 1.89 (medium category) and species evenness index of 0.76 (high category).

\section{Ethical issue}

Authors are aware of, and comply with, best practice in publication ethics specifically with regard to authorship (avoidance of guest authorship), dual submission, manipulation of figures, competing interests and compliance with policies on research ethics. Authors adhere to publication requirements that submitted work is original and has not been published elsewhere in any language.

\section{Competing interests}

The authors declare that there is no conflict of interest that would prejudice the impartiality of this scientific work.

\section{Authors' contribution}

All authors of this study have a complete contribution for data collection, data analyses and manuscript writing.

\section{References}

1. Sinery A.S, Burwos H, Worabay M, Jowey R.N, Setiawan B. 2020. Mammals diversity in the Nutmeg Plantation area at Teluk Wondama and Teluk Bintuni Regency in West Papua Province, Indonesia. World Journal of Advanced Research and Reviews. 2020;05(01);079-085.

2. Islami M.M, Ikhsani I. Y, Indrabudi T, and Pelupessy I.A.H. Diversity, Composition, and Utilization of Mollusk in Saparua Island, Center Moluccas. Widyariset. 2018;4(2):173- 88.

3. Rusnaningsih. The community Structureof Gastropoda and population study of Cerithidea Obtusa (Lamarck 1822) in Pangkal Babu mangrove forest Tanjung Jabung Barat Regency, Jambi. Master Thesis of MIPA Faculty, Indonesia University, Indonesia. 2012.

4. Tapilatu, Y and Pelasula, D. Fouling Organism Associated With Mangrove In Ambon Inner Bay. Journal of Tropical Science and Tecnology. 2012;4(2):267-279.

5. Arbi, U.Y. Taxonomy and hylogeny of Potamidid Snails (Gastropoda:MolluscaI in Indonesia Inferred from Morphological Characters. 2014.

6. Reid, D.G. The Genus Cerithidea Swainson, 1840 (Gastropoda: Potamididae) in the Indo-West Pacific Region. Zootaxa. 2014;3775(1):1-65.

7. Reid, D.G. dan Claremont, M. The Genus Cerithideopsis Thiele, 1929 (Gastropoda: Potamididae) in the Indo-West Pacific Region. Zootaxa. 2014;3779(1):61-80.

8. Nayak, B., Zaman, S., Gadi, S.D., Raha, A.K. and Mitra, A. Dominant Gastropods of Indian Sundarbans: a Major Sink of Carbon. International Journal of Advances in Pharmacy, Biology and Chemistry. 2014;3(2):282-289.
9. Baharuddin, N and Marshall, D.J. Common Aquatic Gastropods of Brunei. Institute for Biodiversity and Environmental Research. Gadong. 2015.

10. Nurrudin, Hamidah A, Kartika W.A. The Diversity of Gastropods Species Around Parit Fish Auction, Tungkal I Village, West Tanjung Jabung. Biospecies. 2015;8(2):51-60.

11. Wahyuni S. The types of moluscs (Gastropoda dan Bivalvia) in the mangrove ecosystem of Dedap village, district of Tasikputripuyu Kepulauan Meranti regency, Riau. Jurnal of FKIP, Universitas Pasir Pangaraian. 2016;2(1).

12. Ludi L.P and Widiastuti A. Molluses Diversity in Coastal Ecosystem of South Biak, Papua. Oseanologi dan Limnologi di Indonesia. 2017;2(1):25-37.

13. Odum, P. Fundamentals of ecology. 3rd ed. Gajah Mada Univ. Press, Yogyakarta, Indonesia. 1993.

14. Sinery A.S. The Management Strategyof Cuscus at Numfor Island Deepublish, Yogyakarta, Indonesia. 2015.

15. Baharuddin N, Basri NB, Syawal NH. Marine gastropods (Gastropoda; Mollusca) diversity and distribution on intertidal rocky shores of Terengganu, Peninsular Malaysia. AACL Bioflux . 2018;11 (4):1144-1154.

16. Belhiouani H, El-Hadef El-Okki M, Afri-Mehennaoui F-Z, Sahli L. Terrestrial gastropod diversity, distribution and abundance in areas with and without anthropogenic disturbances, Northeast Algeria. Biodiversitas. 2019;20(1):243-249.

17. Manullang T, Bakti D, Leidonald R. Structure of gastropod communities at mangrove ecosystem in Lubuk Kertang village, West Berandan District, Langkat Regency, North Sumatera Province. IOP Conf Ser: Earth Environ Sci. 2018;122:1-6.

18. Rumahlatu D, Leiwakabessy F. Biodiversity of gastropoda in the coastal waters of Ambon Island, Indonesia. AACL Bioflux. 2017;10(2):285-296.

19. Silaen I.F, Hendrarto B, Supardjo MN. Distribution and Abudance of Gastropoda in Teluk Awur Jepara Mangrove Forest. Journal of Management of Aquatic Resources. 2013;2(3):93-103.

20. Ayunda R. 2011. The Structure community of gastropoda at mangrove ecosystem in Gugus Pulai Pari Island group, Kepulauan Seribu. Indonesia University, Depok, Indonesia. 2011.

21. Pribadi R, Hartati R, Suryono C.A. Composition and Distribution Of Gastropod Species In Segara Anakan Cilacap Mangrove Forest. Marine Science. 2009;14(2):102-111.

22. Sinery A.S, Farida W.R, Manusawai J. The population of spotted cuscus (Spilocuscus maculatus) and its habitat carrying capacity in Numfor Island, Papua, Indonesia. Biodiversitas. 2016;17(1):315321. DOI: 10.13057/biodiv/d170143

\section{Author Profile:}

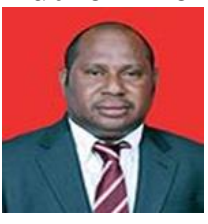

Markus Waran, ST, M.Si, was Born in Oransbari Papua Barat on May 13, 1976. He received undergraduate master degree all majoring environment science 2001 and 2018 and from Sunan Giri University and University of Papua. Curently he is a regent of South Manokwari Regency. He main research in environmental science.

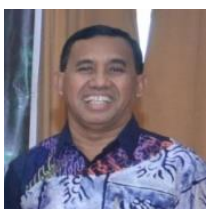

Prof. Dr. Ir. Marlon I. Aipassa, M.Agr, was born in Bogor July 15, 1958. He received undergraduate master and doctor degree all majoring environment science and forestry 1932, 1988 and 1991 and from Mulawarman 
University of Samarinda, Hokkaido University Japan (Soil and Water Conservation). Curently he is a lecturer at Department of Forestry and Environmental Science Mulawarman University. He main research in environmental science (Soil and Water Conservation).

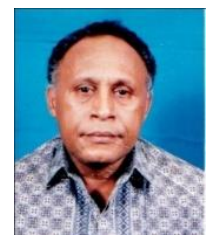

Dr. Jacob Manusawai, was born in Sorong on October 6, 1958. Completed a Bachelor in forest management study program at Universitas Cendrawash in 1986. In 2005 he completed his master of law at the Law Study Program Universitas Hasanuddin Makassar. In 2015 he completed his forestry doctorate at Universitas Malawaraman Samarinda. Since 1989 he has worked as a teaching staff at majoring Forestry, Faculty of Agriculture, Universitas Cenderawasih (currently the Faculty of Forestry, University Papua, Manokwari). His main research on environemtal science and forestry

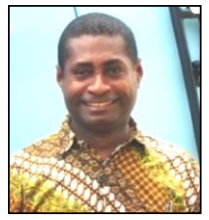

Dr. Anton Silas Sinery, was Born in Waropen, Papua on January 27, 1979. He received undergraduate, master, and doctoral degree all majoring forestry science in 2002, 2008, and 2013 and from Universitas Papua and Universitas Mulawarman.

Currently he is a lecturer at forestry faculty and envoronmental research center University of Papua. His main research in environmental science and forestry 